УДК821.161.2.09-31Чупа

Яременко Наталя, кандидат філологічних наук, доцент, доцент кафедри української та світової літератур Криворізький державний педагогічний університет

\title{
НАСТРІЙ ТЕКСТУ ЯК СКЛАДОВА ЕФЕКТУ ПРИСУТНОСТІ В ПОВІСТІ О. ЧУПИ «ВИШНЯ І Я»
}

У статті зроблено спробу вивчити специфіку моделювання настроєвої парадигми повісті О. Чупи «Вишня $і$ Я» в аспекті продукування присутності. Спираючись на концепцію, репрезентовану в прачі німецько-американського літературознавия, філософа, історика Х. У. Гумбрехта, автором наголошено, щчо будь-яке зіткнення людини і культури, в результаті якого створюється ситуація естетичного перживання, дозволяє відчути елементи як значення (інтерпретація) так $і$ присутності (переживання). Персонажі освоюють реальність иляхом осягнення ії предметності, залучаючи до иъього $і$ свідомість, $i$ тіло. У статті розглядаються провідні модуси буття втілені в повісті О. Чупи «Вишня $і$ Я», що є складовими тілесно-міметичного дискурсу в межах ефекту присутності як здійснення спроби, за висловом Х. У. Гумбрехта, «проникнення крізь матеріальну 
реальність у прагненні освоїти духовну істину», щоб глибше осягнути правду про людину, ї взаємини зі світом.

Ключові слова: ефект присутності, настрій тексту, виробництво присутності, острівний локус, синестезія, предметні образи.

Yaremenko $N$. The text setting as the component of the presence effect in the story of O. Chupa "Cherry and I».

The article attempts to study the specifics of the tunable paradigm simulation of O. Chupa's novel «Cherry and I» in the aspect of presence production. Based on the concept represented in the work of the German-American literary critic, philosopher, historian H. U. Gumbrechto The author pointed out that any clash of man and culture, which creates a situation of aesthetic alertness, allows you to feel the elements as meaning (interpretation) so and presence (experience). Characters master the reality by comprehending its objectivity, involving both consciousness and body. The article deals with the leading modes of being embodied in the story of $O$. Chupa «Cherry and I», which are components of bodily-mimetic discourse within the framework of the presence effect as an attempt to "penetrate through material reality in an effort to master the spiritual truth", in order to better understand the truth about a person, his relationship with the world.

Key words: presence effect, climate of the text, presence effect, island locus, synesthesia, subject images, O. Chupa.

Сучасний літературознавчий дискурс зорієнтований на пошук нових підходів до аналізу художніх творів, які б ураховували не лише смисли (значення, семантична інтерпретація - Х. У. Гумбрехт), а й елементи матеріального вияву, що складають значну частину наших естетичних переживань. Це зумовлено, передусім, прагненням осягнути взаємозв’язки буття окремої особистості з буттям Всесвіту. Культура XXI століття значною мірою тяжіє до метафізичного сприйняття та інтерпретації світу, часто ігноруючи ставлення до буття, закорінене у присутності. Ефект присутності в літературі, зорієнтований на чуттєву сферу, можна, за висловом Ф. Кіттлера, окреслити як «інтелектуальну чутливість» до матеріальних факторів [4, с. 173-188]. Оскільки революція електронних засобів комунікації призводить до часткової дематеріалізації людського життя, й супроводжується втратою тілесності, на думку Х. У. Гумбрехта, важливо враховувати, що предметний світ крім свого матеріального буття наділений також внутрішнім смислом (а не лише смислом, що надається останньому при інтерпретації) [3, с. 87]. Криза метафізики (як чіткої системи понять) проявлена через руйнацію зв’язків емпіричного й трансцедентального «Я», результатом якої $\epsilon$ 
часткова деформація ідентичності суб’єкта, ініціює формування нетривіальних підходів до сприйняття артефактів культури, зокрема творів літератури.

Спираючись на концепцію, репрезентовану в праці німецькоамериканського літературознавця, філософа, історика Х. У. Гумбрехта, можна стверджувати, що будь-яке зіткнення людини і культури, в результаті якого створюється ситуація естетичного перживання, дозволяє відчути елементи як значення (інтерпретація) так і присутності (переживання). Пропорційність цих компонентів залежить від способа комунікації, предмета естетичного переживання [3, с. 112]. Крім того, ефекти присутності не можна зафіксувати, вони ефемерні, їх темпоральність можна описати словом «подія». Текст, і в першу чергу художній текст, на думку Жана-Люка Нансі, являє собою думку, направлену в бік тіла, того, що іiї сприймає й обособлює $[12$, с. 6].

Творчий доробок сучасного українського прозаїка О. Чупи, який нині є чи не найбільш відвертим і глибоким репрезентантом реалій Донецького регіону, вочевидь досліджений недостатньо. У центр уваги літературознавців потрапили його романи. Так, у статті С. Ушкевич досліджено специфіку авторського мислення крізь призму альтернативного моделювання історії в художньому просторі роману «Бомжі Донбасу» [10]. Предметом осмислення у праці Ю. Вишницької стали проблема особистісної ідентифікації та релевація колективної й особистісної історії в романі О. Чупи «Акваріум» [1]. Я. Поліщук вивчає специфіку відтворення локальної ідентичності донецького регіону у романі «Казки бомбосховища». Дослідник послідовно доводить, що в центрі уваги письменника, передусім, постають люди Донеччини. Літературознавець зазначає: «О. Чупа прагне вивести колективний образ своєї батьківщини 3 тіні традиційної непроявленості та сіризни, наповнивши його живим, колоритним змістом. Почуття загроженості й незахищеності - тим паче тепер, в умовах війни, підсилене, підкреслене, гіперболізоване, - не тільки визначає їхню ідентичність, а й зумовлює іiї загальмованість, несприйнятливість до раціональних аргументів» [9, с. 5]. 
Повість «Вишня i Я» явно дисонує 3 попередніми творами. Письменником зроблено надзвичайно вдалу спробу на зміну раціональній людині змоделювати людину чуттєву, здатну співпереживати, «думати серцем». Вивчення у творі провідних модусів буття, які є складовими тілесноміметичного дискурсу в межах ефекту присутності як здійснення спроби «проникрення крізь матеріальну реальності у прагненні освоїти духовну істину» [3, с. 87], дають можливість глибше осягнути правду про людину, іiі взаємини зі світом, що й обумовлює актуальність нашого дослідження.

Метою статті є вивчення специфіки моделювання настроєвої парадигми повісті О. Чупи «Вишня і Я» в аспекті продукування присутності.

Виклад основного матеріалу. Як зауважив в одному 3 інтерв’ю сам автор, повість «Вишня і Я»-це історія покинутої дитини й дорослого чоловіка, у яку вкладено багато власного досвіду спілкування із дитиною, що живе в душі митця.

Досліджуваний твір вибудуваний на кшталт казки, де світомодель сформована у вигляді «острівного локуса», що, за Ю. Лотманом, «по відношенню до героя є функціональним полем, потрапляння в яке рівнозначне потраплянню в конфліктну ситуацію, властиву саме цьому locus`y» [8, с. 253]. Місцем, де відбувається дійство є будинок Ярчика, монументальна споруда, що «<..> піднімається над верхівками каштанів і тополь. Насувається своїми чотирма поверхами <..> нагадує корабель. Доглянутий, освілений, величезний пароплав» [12, с. 10]. Закритий простір будинку-корабля і території навколо, якій Вишня дає свої наймення («Котіївка», «Зазавок») сприймається як зона безпеки, своєрідною ланкою, що інтегрує людину і світ, створює своєрідну естетичну автономію. Дім Ярчика спочатку стає для Вишні втіленням всього світу речей. Тому перші дні свого перебування там дівчинка присвячує вивченню середовища, намагаючись не лише роздивитися, торкнутися, понюхати все навколо, а порахувати, відкривши для себе «<..> новий світ. Вищий. Ширший. Яскравіший» [12, с. 12]. Вона почувається в безпеці, «щуасливо i радісно», адже «велетень привів эї до своєї потаємної печери. Вишня 
почувається Королевою, не менше» $[12$, с. 15]. Дівчинка освоює реальність шляхом осягнення іiї предметності, залучаючи до цього і свідомість, і тіло.

Згідно тезі про «життєвий світ», висунутій ще Е. Гусерлем i актуалізованій Х. У. Гумбрехтом, відбувається реабілітація повсякденності. Так, Вишня, вперше залишившись вдома сама, методично порушує всі встановлені «Велетнем» правила: «иукає ножі», «крутить газові краники», «відчиняє зсередини двері» [12, с. 38]. «Клямка, здається, уважно ї̈ слухає. На знак згоди тьмяно полискуе довгастою лакованою поверхнею» [12, с. 38]. Дівчинка «Вивчає предмети. На запах. На дотик. На звук. На смак, ясна річ, також. Найбільше їй подобаються як пахнуть старі газети $i$ мімечки $з$ приправами. Найприємніший звук - телефонний дзвінок. На дотик найприємнішим $\epsilon$ ї̈ волосся» [12, с. 41]. Таким чином створюється «ефект присутності», стан особливого відчуття матеріального світу, в який людина повністю занурюється i сприймає через зовнішні рецептори як прояви тілесного. Повтор «найприємніший» увиразнює емоційно-психологічне сприйняття дитиною дійсності. Завдяки використанню лексичного повтору авторові вдається вибудувати об’ємну модель реального. Дівчинці «щасливо $i$ радісно» від усього, що її оточує [12, с. 15].

Саме «острівний стан» i специфічний настрій «зосередженої інтенсивності» створює умови для переживання коливань між значенням i присутністю [4, с. 110]. У повісті реальний час персонажів виписаний як відбиток, результат просторового ставлення до світу та його елементів («присутність») [4, с. 11]. Предметний час не сприймається як безперервність. Його кінечність чітко окреслено: Ярчик і Вишня домовилися, що їхнє літо триватиме сто днів. «Вона ж бо вміє рахувати до циілої сотні» [12, с. 11] і далі: «Як я знатиму, скільки днів ми з тобою занайомі? Треба щодня купувати один помаранч. Коли їх стане сотня - можна їсти» [12, с. 23]. Кожен літній день втілюється в образі яскравого усміхненого помаранча, який постає у творі своєрідним психологічним асоціативом. Так, «Вже трьома або чотирма помаранчами пізніме» [12, с. 27], «<..> коли кількість помаранчів перевалила 
за півтора десятка, Ярчик перестав ховати від неї ножі» [12, с. 41] або «3 часу цієї розмови на полищю холодильника прикотилося ще кілька яскравих помаранчів» [12, с. 42].

Відраховуючи час, нанизуючи на часову вісь веселі яскраві ароматні намистини, герої змінюються. Вишня дорослішає, освоює життєві навички, 3 черговим помаранчем проявляє себе в новому світлі. Спочатку навчається залишатися на самоті, вести елементарне господарство, потім Ярчик довіряє їй ключ від квартири, дівчинка починає дружити зі своїми однолітками. Образ помаранча стає в повісті наскрізним, сприяє організації оповіді. У психології оранжевий вважається кольором творчого начала, натхнення та ентузіазму, піднімає настрій, пробуджує прагнення творити. Він виступає природним знаком та уособлює внутрішню силу особистості, ії прагнення до розвитку.

Повість поділено на чотири розділи: «червень - місяиь несподіванок $i$ спеки» [12, с. 5], «липень - вологий і зелений» [12, с. 49], «серпень - це останній літній місящь» [12, с. 87], «вересень, коли все як влітку» [12, с. 126]. Структура твору відбиває цю локалізованість, адже, як зазначено Д. Лихачовим, «казковий час не виходить за межі казки. Він повністю замкнутий у сюжеті. Він не визначений у потоці історичного часу» [6, с. 231].

Складність, багатогранність чуттєвого сприйняття матеріального світу персонажами втілено в колористичних образах. Яскравим прикладом може бути промовистий синеститичний перенос: «<..> останнє його слово тоне в музииі. <...> «Gold day in Hell». Довкола одразу стає жовто. Цей блюз фарбує у жовте посуд, стіни кухні і Ярчика з Вишнею. Випаленої, сліпучої жовтизни набуває сухе червневе небо і цегляний димар, щчо рветься вгору поряд із вікном. Жовтавіють перехожі, асфальт $і$ дворові коти» [12, с. 17]. Міжчуттєва асоціація сформована завдяки нашаруванню двох чуттєвих образів створює неочікувані враження. Візуально-аудіальна синестезія дозволяє митцеві вивести метафору на рівень символу, який «<..> може викликати в читача довгий ряд aсоиіаиій» [7, с. 158]. 
Залучення колористичного образу активізує тонкий почуттєвий нюанс. Ще Й. В. Гете у трактаті «Вчення про колір» [2] розробив шкалу кольорів, де жовтий, оранжевий, червоний знаходяться на позитивному настроєвому полюсі, сприймаючись як екстенсивні, динамічні, стимулюючі. Не даремно, звучання блюза сприймається персонажами в золотавих тонах. Світ, забарвлюється в жовтий колір, чим створюється рухлива позитивна атмосфера. Авторське семантичне поле, визначене контекстом не співпадає із традиційним: у жовтавій гамі зазвичай постає осінь («золота»), у повісті ж мова йде про початок літа. Основана на синтезі відчуттів картина відбиває комплексний характер процесу сприйняття навколишнього персонажами в його єдності й гармонії. Подібна гармонія, як слушно зауважує Н. Коломієць, «<..> досягається саме завдяки віднайденню внутрішніх потенцій, налаштуванню на творчий пошук, готовності нести у світ добро» [5, с. 163]. I Ярчик, і Вишня перебувають у стані щасливої безхмарності, щастя, руху й очікують щастя. Дівчинка «<..> розчинясться в музищі. На неї котиться хвилями чарівне тепло, щяо лине від Ярчикової пісні. На иих хвилях вона гойдається і сміється. Разом з нею гойдасться і весь світ довкола» [12, с. 124].

Таким чином, настрій тексту повісті О. Чупи «Вишня і Я» як стійкий емоційний стан формується на всіх рівнях його художньої структури i налаштовує читача на переживання радості, піднесення, «зцілення» [12, с. 125]. Інтонація тексту досліджуваної повісті сприймається як така, що сповнена позитивних оцінок і емоцій. Вона створюється значною мірою через проявлене ставлення автора до зображуваного.

\section{Література}

1. Вишницька Ю. Колоніальні тенета, або Як залишитися людиною в акваріумі? (на матеріалі роману-антиутопії Олексія Чупи «Акваріум») / Юлія Вишницька // Проблема ідентичностей у сучасній українській літературі : виміри «Коронації слова» : монографія ; наук. ред. Н. І. Богданець- 
Білоскаленко, О. О. Бровко. - Чернівці : Видавничий дім «Бук рек», 2018. 224 c. - C. $49-60$.

2. Гете Й. В. Учение о цвете. - Режим доступу : http://www.psyworld.info

3. Гумбрехт Х. У. Производство присутствия : Чего не может передать значение ; пер. с англ. С. Зенкина. - Москва : Новое литературное обозрение. 2006. $-184 \mathrm{c}$.

4. Киттлер Ф. Медиа философии / Ф. Кеттлер // Логос. - 2015. - №2. C. $13-188$.

5. Коломієць Н. Є. Соціально-психологічні аспекти особистості та художні форми їх вираження у творчості Б. Д. Грінченка (на матеріалі поезії та малої прози) : дис. канд. філ. наук : 10.01 .01 / Коломієць Наталія Євгенівна Дніпропетровськ, 2000. - 220 с.

6. Лихачев Д. С. Замкнутое время сказки. Поэтика древнерусской литературы / Дмитрий Лихачев. - Ленинград : Наука. 1967. - 231 с.

7. Лосев А. Ф. Проблема символа и реалистическое искусство / А. Ф. Лосев. - М. : Искусство. - 1986. - 367 с.

8. Лотман Ю. В школе поэтического слова : Пушкин. Лермонтов. Гоголь / Юрий Лотман. - Москва : Просвещение, 1988. - 253 с.

9. Поліщук Я. / Ярослав Поліщук // Національна ідентичність в мові і культурі: збірник наукових праць ; за заг. ред. А. Г. Гудманяна. О. Г. Шостак. К. : Талком, 2017. - 343 с. - С. 5-8. - Режим доступу : http://er.nau.edu.ua/ bitstream/NAU/

10.Ушневич С. С. Альтернативне моделювання історії в романному просторі О. Чупи «Бомжі Донбасу» / С. Е. Ушневич // Вісник Запорізького національного університету. - Серія : Філологічні науки. - 2014. - № 2. C. 242-247. - Режим доступу : http://nbuv.gov.ua/UJRN/vznu_fi_2014_2_32/

11.Филоненко А. «Производство присутствия» и новая культурная чувствительность: «нескромное предложение» Ханса Ульриха Гумбрехта и его академические расширения / Александр Филоненко // Койнония / Вестник ХНУ им. В. Н. Каразина. - 2010. - № 904. - С. 49-75. 
12.Чупа О. Вишня і Я. [Текст] : повість / Олексій Чупа. - Львів : Видавництво Старого Лева, 2016. - 128 с.

13.Nancy, Birth to Presence. - 440 p. p. 6. - Режим доступу : https://books. google.com.ua/books/ 